\title{
Sistem Rekomendasi Kelanjutan Kontrak Karyawan Menggunakan Metode Topsis
}

\author{
Hata Maulana, Putri Kusuma Wardani \\ Program Studi Teknik Informatika \\ Politeknik Negeri Jakarta, \\ Depok, Indonesia \\ hata.maulana@tik.pnj.ac.id
}

Diterima: 3 April 2018. Disetujui: 22 April 2018. Dipublikasikan: Mei 2018

\begin{abstract}
Abstrak - Praktik outsourcing dalam dunia usaha di Indonesia telah lama berlangsung. Hal ini tidak terlepas dari alasan utama perusahaan pengguna jasa untuk melakukan outsource. Outsource dipandang sebagai langkah efisiensi bagi perusahaan pengguna jasa untuk lebih fokus melakukan bisnis pokoknya. Hal ini tentu mendorong munculnya perusahaan penyedia jasa outsourcing yang mulai banyak ditemukan saat ini. Sebagai studi kasus adalah PT Mitra Hexa Sejahtera. Namun, dalam praktiknya, PT Mitra Hexa Sejahtera menemukan berbagai permasalahan dalam pengelolaan operasional yang belum dikelola dengan baik sehingga mempengaruhi kinerja karyawan tersebut. Permasalahan itu diantaranya, pengelolaan data absensi dan lembur yang masih berupa kertas sehingga memungkinkan file tersebut hilang atau rusak, belum adanya sistem pendukung keputusan untuk evaluasi kinerja karyawan outsourcing sehingga manager HRD seringkali kesulitan dalam menentukan perpanjangan kontrak karyawan, dan belum adanya sistem yang terkait dengan informasi masa kontrak client dan karyawan outsourcing sehingga perusahaan tidak mengetahui secara pasti masa kontrak yang akan berakhir. Sistem rekomendasi kelanjutan kontrak karyawan dengan TOPSIS ini dibangun berbasis web dengan menggunakan bahasa pemrograman PHP, framework CodeIgniter dan dilengkapi metode Technique for Order Preference by Similarity to Ideal Solution (TOPSIS) untuk evaluasi kinerja karyawan outsourcing.
\end{abstract}

Kata Kunci: outsourcing, sistem rekomedasi, kontrak karyawan, berbasis web, TOPSIS.

\section{PENDAHULUAN}

Berdasarkan hasil wawancara dengan pihak Human Resource Department (HRD) PT Mitra Hexa Sejahtera, ditemukan beberapa permasalahan dalam pengelolaan operasional karyawan outsourcing mereka. Permasalahan itu diantaranya, pengelolaan data absensi dan lembur yang masih berupa kertas menghambat kinerja staf departemen HRD dalam memproses penggajian karyawan, sulitnya mencari informasi mengenai data karyawan, masa kontrak klien dan karyawan, dan informasi lainnya karena data disimpan dalam file, kriteria evaluasi karyawan outsourcing memiliki subjektifitas yang tinggi sehingga pendapat pribadi penilai seringkali mempengaruhi penilaian kinerja baik dalam arti positif maupun negatif. Selain itu, evaluasi karyawan tidak mendapatkan prioritas yang tinggi sehingga hanya dilakukan setiap enam bulan sekali atau hanya ketika klien meminta dilakukan evaluasi karena evaluasi membutuhkan banyak waktu.

Metode pengembangan sistem yang digunakan dalam penelitian ini adalah metode Rational Unified Process (RUP) yang menggunakan pendekatan pengembangan perangkat lunak yang dilakukan berulang-ulang (iterative), fokus pada arsitektur (architecture-centric), dan lebih diarahkan berdasarkan penggunaan kasus (use case driven). Penelitian dimulai dengan tahap inception yang terdiri dari perencanaan, penelitian, analisis. Kemudian mengumpulkan referensi yang berkaitan dengan dasar-dasar sistem pendukung keputusan dan metode Technique for Order Preference by Similarity to Ideal Solution (TOPSIS) yang digunakan untuk menjelaskan rumus-rumus yang ada didalamnya. Tahap yang kedua (elaboration) adalah perancangan, model proses, dan pemodelan data. Tahap ketiga (construction) mengimplementasikan rancangan, tahap terakhir (transition) melakukan pengujian sistem yang telah dibuat.

Berdasarkan penelitian-penelitian yang pernah dilakukan tentang sistem pendukung keputusan penilaian kinerja karyawan, maka penelitian ini didasari pada penelitian sebelumnya yang berjudul "Sistem Pendukung Keputusan Penentuan Karyawan Kontrak Menjadi Karyawan Tetap Menggunakan Metode TOPSIS" [5]. Pada penelitian ini dijelaskan bahwa bagaimana sistem ini dapat membantu perusahaan dalam pengambilan keputusan pemilihan karyawan yang tepat untuk diangkat menjadi karyawan tetap di PT Gowa Motor Group.

Perbedaan penelitian yang dilakukan dengan peneliti sebelumnya adalah penelitian yang dibuat menghasilkan sebuah modul pengelolaan operasional karyawan outsourcing yang dilengkapi dengan menggunakan sistem pendukung keputusan penilaian 
kinerja karyawan outsourcing menggunakan metode Technique for Order Preference by Similarity to Ideal Solution (TOPSIS), dimana sistem ini dapat menghitung tingkat kelayakan karyawan outsourcing untuk direkomendasikan perpanjangan kontrak, serta dapat memberikan manfaat dalam pengambilan keputusan untuk penilaian kinerja karyawan outsourcing.

\section{TINJAUAN PUSTAKA}

\section{A. Sistem Informasi Sumber Daya Manusia}

Sistem Informasi Sumber Daya Manusia atau Human Resource Information System (HRIS) atau Human Resource Management System (HRMS) adalah aplikasi perangkat lunak yang menggabungkan berbagai fungsi sumber daya manusia, termasuk administrasi, penggajian, perekrutan, dan evaluasi kinerja dalam satu paket. HRMS memungkinkan perusahaan untuk mengotomatisasi banyak aspek manajemen sumber daya manusia dengan manfaat ganda mengurangi beban kerja departemen Human Resource (HR) serta meningkatkan efisiensi departemen HR dengan standarisasi proses HR. [1]

\section{B. Rational Unified Process}

Metode pengembangan perangkat lunak yang diterapkan pada penelitian ini adalah Rational Unified Process (RUP). Rational Unified Process (RUP) adalah suatu kerangka kerja proses pengembangan perangkat lunak iteratif yang dibuat oleh Rational Software, suatu divisi dari IBM corporation sejak 2003. Metode rekayasa perangkat lunak ini dikembangkan dengan mengumpulkan berbagai best practice yang terkandung dalam industri pengembangan perangkat lunak. [2]

\section{Tahapan Metode Rational Unified Process}

Siklus hidup perangkat lunak dibagi menjadi beberapa siklus, setiap siklus bekerja pada sebuah generasi baru produk. Rational Unified Process membagi satu siklus pembangunan pada empat fase yang berurutan [3] :

1. Fase Inception

Selama fase inception, hal yang dilakukan yaitu membangun business case untuk sistem yang dibuat dan membatasi ruang lingkup sistem.

2. Fase Elaboration

Tujuan dari fase elaboration adalah untuk menganalisis permasalahan, membangun rancangan dasar arsitektural, mengembangkan rencana proyek, dan menghilangkan resiko tertinggi dari proyek tersebut. Fase ini adalah fase yang sangat penting dari keempat fase RUP.

\section{Fase Construction}

Selama fase construction, seluruh komponen dan fitur aplikasi dibangun dan di integrasikan ke dalam produk, serta semua fitur diuji sepenuhnya.

4. Fase Transition

Tujuan dari fase transition adalah untuk peralihan dari produk perangkat lunak kepada komunitas pengguna. Fase transisi dimulai ketika produk sudah cukup siap untuk diserahkan kepada pengguna akhir.

\section{CodeIgniter (CI)}

CodeIgniter (CI) merupakan aplikasi open source yang berupa framework PHP dengan model MVC (Model, View, Controller) untuk membangun website dinamis dengan menggunakan PHP. CodeIgniter memudahkan developer untuk membuat aplikasi web dengan cepat dan mudah dibandingkan dengan membuatnya dari awal. CodeIgniter dirilis pertama kali pada 28 Februari 2006. Versi stabil terakhir adalah versi 3.1.4. Sedangkan versi yang digunakan pada penelitian ini adalah versi 3.1.3. [4] CodeIgniter adalah framework yang menggunakan model MVC (Model, View and Controller) untuk membangun sebuah website yang dinamis dengan menggunakan php. Framework ini adalah turunan dari php sehingga struktur kodingnya tidak jauh berbeda dari php. Model View Controller ini memudahkan seorang developer dalam membangun sebuah aplikasi website dan desain tampilan yang terstruktur sehingga dengan model ini dalam maintenance website sangat mudah. [4]

\section{E. MariaDB}

MariaDB adalah sebuah implementasi dari sistem manajemen basis data relasional (RDBMS) yang didistribusikan secara gratis dibawah lisensi GPL (General Public License). Secara teori semua program yang dibangun menggunakan MySQL bisa berjalan pula dengan MariaDB. Terdapat beberapa Application Programming Interface (API) tersedia yang memungkinkan aplikasi-aplikasi komputer yang ditulis dalam berbagai bahasa pemrograman untuk dapat mengakses basis data MariaDB antara lain C, C++, C\#, Java, Perl, PHP, Python, dan Ruby. [5]

MariaDB dikembangkan sebagai perangkat lunak open source dan database relasional karena menyediakan antarmuka SQL untuk mengakses data. Versi terbaru dari MariaDB juga fitur termasuk GIS dan JSON. Pada penelitian ini versi MariaDB yang digunakan adalah MariaDB 10.1.21 yang rilis pada 18 Januari 2017. [5]

\section{F. Technique for Order Preference by Similarity to Ideal Solution (TOPSIS)}

Technique for Order Preference by Similarity to Ideal Solution (TOPSIS) adalah metode pendukung keputusan multikriteria, yang pada 
awalnya dikembangkan oleh Hwang dan Yoon pada tahun 1981 dengan perkembangan lebih lanjut oleh Yoon pada tahun 1987, dan Hwang, Lai dan Liu pada tahun 1993. [6]

TOPSIS didasarkan pada konsep bahwa alternatif yang dipilih harus memiliki jarak terpendek dari positive ideal solution (PIS) dan jarak terpanjang dari negative ideal solution (NIS). TOPSIS adalah metode yang membandingkan seperangkat alternatif dengan mengidentifikasi bobot untuk setiap kriteria, menormalisasi skor untuk setiap kriteria dan menghitung jarak antara masing-masing alternatif dan alternatif ideal, yang merupakan nilai terbaik setiap kriteria. [7]

Metode TOPSIS digunakan sebagai suatu upaya untuk menyelesaikan permasalahan Multiple Criteria Decision Making (MCDM), salah satunya penentuan perpanjangan kontrak karyawan outsourcing. [8] Hal ini disebabkan konsepnya yang sederhana dan mudah dipahami, komputasinya efisien dan memiliki kemampuan untuk mengukur kinerja relatif dari alternatif-alternatif keputusan. [9]

\section{G. Langkah-langkah penghitungan TOPSIS}

Langkah-langkah penghitungan TOPSIS adalah sebagai berikut [10] :

Menghitung Matriks Ternormalisasi

$R_{i j}=\frac{x_{i j}}{\sqrt{\sum_{i=1}^{m} x_{i j}^{2}}} ;$ dimana $\mathrm{i}=1,2, . ., \mathrm{m} ;$ dan $\mathrm{j}=1,2, . ., \mathrm{n}$

Menghitung Matriks Ternormalisasi Terbobot

$y_{i j}=w_{i} r_{i j}$; dimana $\mathrm{i}=1,2, \ldots, \mathrm{m} ;$ dan $\mathrm{j}=1,2, \ldots, \mathrm{n}$

Menentukan Matriks Solusi Ideal Positif dan Matriks Solusi Ideal Negatif

$$
\begin{aligned}
& A^{+}=\max \left(y_{1}^{+}, y_{2}^{+}, \ldots, y_{n}^{+}\right) \\
& A^{-}=\max \left(y_{1}^{-}, y_{2}^{-}, \ldots, y_{n}^{-}\right)
\end{aligned}
$$

Menghitung Jarak Matriks Solusi Ideal Positif dan Matriks Solusi Ideal Negatif

$$
\begin{aligned}
& D_{i}^{+}=\sqrt{\sum_{j=1}^{n}\left(y_{i}^{+}-y_{i j}\right)^{2}} ; \mathrm{i}=1,2, \ldots, \mathrm{m} \\
& D_{i}^{-}=\sqrt{\sum_{j=1}^{n}\left(y_{i}^{-}-y_{i j}\right)^{2}} ; \mathrm{i}=1,2, \ldots, \mathrm{m}
\end{aligned}
$$

Menghitung Nilai Preferensi untuk Setiap Alternatif

$$
V_{i}=\frac{D_{i}^{-}}{D_{i}^{-}+D_{i}^{+}} ; \text {dimana } \mathrm{i}=1,2,3, \ldots \mathrm{m}
$$

\section{ANALISIS DAN PERANCANGAN SISTEM}

\section{A. Analisis Kebutuhan}

Berikut deskripsi dan analisis dari desain modul operasional. Berdasarkan hasil analisis masalah dari wawancara yang dilakukan bersama staff HRD, terdapat beberapa kebutuhan pengguna yang ditemukan di antaranya:

- Dibutuhkan fitur client,

- Dibutuhkan fitur employee,

- Dibutuhkan fitur attendance,

- Dibutuhkan fitur severence proposal,

- Dibutuhkan fitur tracking contract,

- Dibutuhkan fitur performance appraisal untuk menentukan perpanjangan kontrak karyawan outsourcing.

\section{B. Hasil Analisis Solusi}

Berdasarkan analisis masalah dari hasil wawancara dengan pihak operasional HRD, maka

\begin{tabular}{|c|c|c|c|}
\hline No & $\begin{array}{l}\text { Harapan } \\
\text { Pengguna }\end{array}$ & Kondisi Saat Ini & Solusi \\
\hline 1. & $\begin{array}{l}\text { Mendapat- } \\
\text { kan informasi } \\
\text { lengkap } \\
\text { mengenai } \\
\text { karyawan, } \\
\text { client, dan } \\
\text { masa kontrak } \\
\text { karyawan } \\
\text { outsourcing }\end{array}$ & $\begin{array}{l}\text { Sulitnya mendapatkan } \\
\text { informasi mengenai masa } \\
\text { kontrak kerja karyawan, } \\
\text { sehingga pihak HR tidak } \\
\text { memiliki cukup waktu } \\
\text { untuk mempersiapkan } \\
\text { perekrutan, informasi } \\
\text { mengenai data karyawan } \\
\text { dan data client karena } \\
\text { data disimpan dalam } \\
\text { berkas-berkas pada file } \\
\text { kabinet sehingga } \\
\text { memungkinkan data } \\
\text { tersebut hilang atau rusak, } \\
\text { sulit mencari data-data } \\
\text { penting tersebut saat } \\
\text { sewaktu-waktu } \\
\text { dibutuhkan } \\
\text { pengguna. }\end{array}$ & $\begin{array}{l}\text { Menyediakan } \\
\text { fitur Client yang } \\
\text { dapat } \\
\text { memberikan } \\
\text { informasi } \\
\text { mengenai client, } \\
\text { fitur Employee } \\
\text { yang dapat } \\
\text { memberikan } \\
\text { informasi } \\
\text { mengenai } \\
\text { karyawan dan } \\
\text { fitur Tracking } \\
\text { Contract yang } \\
\text { dapat } \\
\text { memberikan } \\
\text { informasi } \\
\text { mengenai masa } \\
\text { kontrak } \\
\text { karyawan } \\
\text { sehingga user } \\
\text { dapat mat } \\
\text { mempersiapkan } \\
\text { perekrutan jika } \\
\text { terdapat } \\
\text { karyawan yang } \\
\text { dalam jangka } \\
\text { waktu kurang } \\
\text { dari satu bulan } \\
\text { habis masa } \\
\text { kontraknya. }\end{array}$ \\
\hline 2. & \begin{tabular}{l|} 
Dapat \\
melakukan \\
dalam \\
pengelolaan \\
absen dan \\
lembur
\end{tabular} & $\begin{array}{lr}\text { Sulitnya } & \text { melakukan } \\
\text { pengelolaan data } & \text { absen } \\
\text { dan lembur } & \text { karena } \\
\text { dilakukan secara terpisah, } \\
\text { sehingga } & \text { pengguna } \\
\text { melakukan } & \text { pengecekan }\end{array}$ & $\begin{array}{lr}\text { Adanya fitur } \\
\text { Time and } \\
\text { Attendance yang } \\
\text { dapat membantu } \\
\text { mengelola absen } \\
\text { dan lembur }\end{array}$ \\
\hline
\end{tabular}
didapatkan hasil analisis solusi dari data dan informasi yang diperoleh seperti yang ditunjukkan pada Tabel 1 .

TABEL 1. HASIL ANALISIS SOLUSI 


\begin{tabular}{|c|c|c|c|}
\hline & $\begin{array}{l}\text { karyawan } \\
\text { secara } \\
\text { efesien }\end{array}$ & $\begin{array}{l}\text { secara berulang untuk } \\
\text { menyesuaikan data absen } \\
\text { dan lembur. }\end{array}$ & $\begin{array}{l}\text { karyawan } \\
\text { sehingga data- } \\
\text { data tersebut } \\
\text { dapat } \\
\text { terintegrasi. }\end{array}$ \\
\hline 3. & $\begin{array}{l}\text { Dapat } \\
\text { melakukan } \\
\text { pengelolaan } \\
\text { data } \\
\text { pemutusan } \\
\text { kontrak } \\
\text { karyawan }\end{array}$ & $\begin{array}{l}\text { Sulitnya mendapatkan } \\
\text { rekam jejak (track } \\
\text { record) mengenai data } \\
\text { pemutusan kontrak kerja } \\
\text { karyawan, baik resign } \\
\text { maupun pemutusan } \\
\text { hubungan kerja. }\end{array}$ & $\begin{array}{l}\text { Adanya fitur } \\
\text { Severence } \\
\text { Proposal yang } \\
\text { dapat } \\
\text { melakukan } \\
\text { pengelolaan } \\
\text { pemutusan } \\
\text { kontrak } \\
\text { karyawan. }\end{array}$ \\
\hline 4. & $\begin{array}{l}\text { Dapat } \\
\text { melakukan } \\
\text { evaluasi } \\
\text { karyawan } \\
\text { outsourcing } \\
\text { dengan } \\
\text { efisien dan } \\
\text { hasil yang } \\
\text { akurat }\end{array}$ & $\begin{array}{l}\text { Sulitnya melakukan } \\
\text { evaluasi karyawan karena } \\
\text { membutuhkan waktu dan } \\
\text { effort yang banyak } \\
\text { sehingga evaluasi } \\
\text { dilakukan setiap enam } \\
\text { bulan sekali atau hanya } \\
\text { ketika client meminta } \\
\text { dilakukan evaluasi. }\end{array}$ & $\begin{array}{l}\text { Adanya fitur } \\
\text { Performance } \\
\text { Appraisal yang } \\
\text { dapat } \\
\text { melakukan } \\
\text { penghitungan } \\
\text { secara efektif } \\
\text { dan memberikan } \\
\text { hasil evaluasi } \\
\text { yang akurat } \\
\text { untuk } \\
\text { menentukan } \\
\text { rekomendasi } \\
\text { perpanjangan } \\
\text { kontrak } \\
\text { karyawan. }\end{array}$ \\
\hline
\end{tabular}

C. Pemodelan Sistem

\section{Use case}

Untuk menjelaskan use case dan aktor yang terkait dengan sistem ini, dipertimbangkan peran dan fungsi yang telah diuraikan di atas. [11] Berikut skenario dari modul operasional.

- Super Admin merupakan aktor yang bertindak sebagai admin utama dan memiliki hak akses untuk mengelola (Create, Read, Update, Delete) seluruh fitur yang terdapat pada sistem HRMS.

- Admin Operasional merupakan aktor yang bertindak sebagai admin pada modul operasional dan memiliki hak akses terhadap fitur client, employee, severance proposal, tracking contract, dan time and attendance pada modul operasional untuk membuat dan melihat (Create, Read).

- Supervisor merupakan aktor yang bertindak sebagai pengguna pada modul operasional dan memiliki hak akses terhadap fitur performance appraisal untuk membuat data evaluasi dan melihat data hasil evaluasi.

Diagram use case lebih jelas dapat dilihat pada Gambar 1.

\section{Diagram Aktifitas}

Diagram aktifitas menggambarkan berbagai alir aktifitas dalam sistem yang sedang dirancang, bagaimana masing-masing alir berawal, keputusan yang mungkin terjadi, dan bagaimana berakhir. [11] Suatu aktifitas dapat direalisasikan oleh satu use case atau lebih, aktifitas menggambarkan proses yang sedang berjalan, sedangkan use case menggambarkan bagaimana aktor menggunakan sistem untuk melakukan aktifitas. Contoh diagram aktifitas dapat dilihat pada Gambar 2.

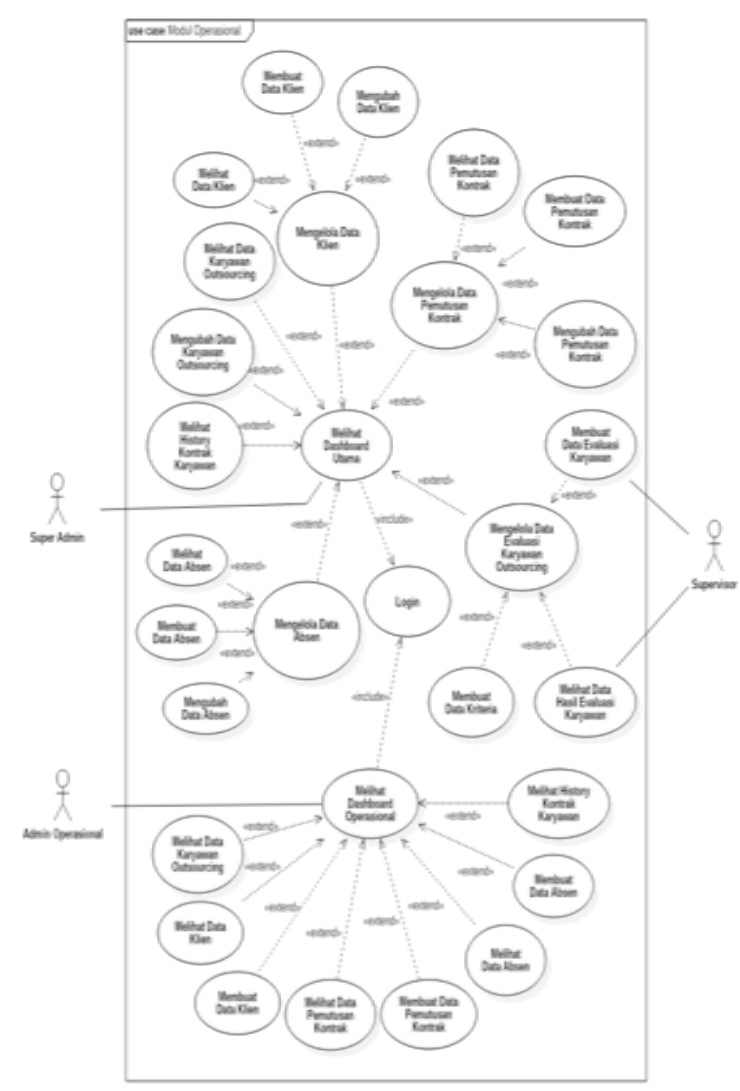

Gambar 1. Diagram Use Case Sistem

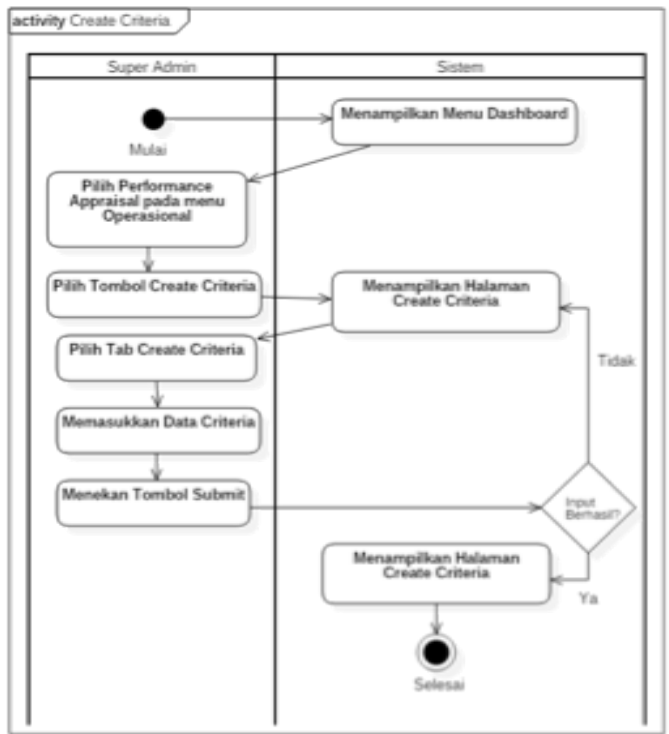

Gambar 2. Diagram Aktifitas Dari Use Case Membuat Data Kriteria (Aktor: Super Admin)

\section{Diagram Kelas}

Kelas adalah sebuah spesifikasi yang jika diinstansiasi akan menghasilkan sebuah obyek dan 
merupakan inti dari pengembangan dan desain berorientasi obyek. Kelas menggambarkan keadaan (atribut/property) suatu sistem, sekaligus menawarkan layanan untuk memanipulasi keadaan tersebut (metoda/fungsi) [11].

\section{Diagram Sequence}

Diagram sequence biasa digunakan untuk menggambarkan skenario atau rangkaian langkah yang dilakukan sebagai respons dari sebuah event untuk menghasilkan keluaran tertentu. Diawali dari apa yang memicu aktifitas tersebut, proses dan perubahan apa saja yang terjadi secara internal dan keluaran apa yang dihasilkan [11]. Contoh diagram sequence dapat dilihat pada Gambar 3.

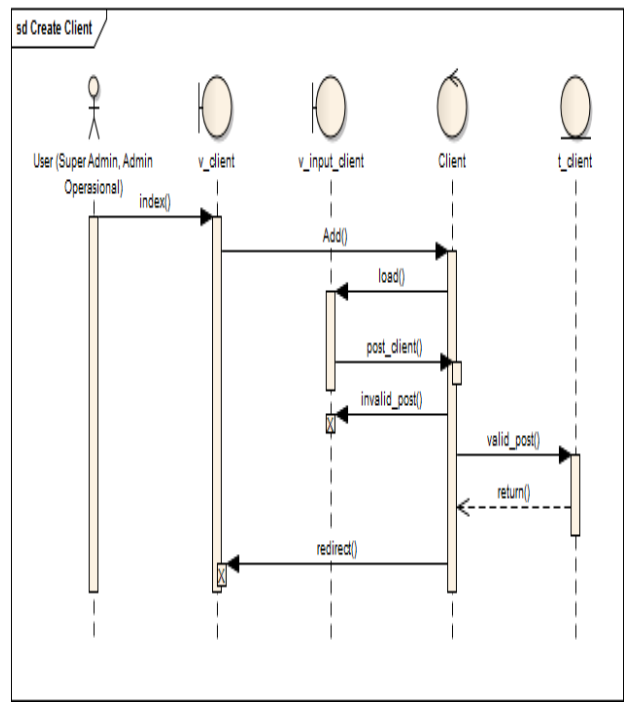

Gambar 3. Diagram Sequence Untuk Use Case Create Client

\section{Implementasi Dan Pengujian Sistem}

Pada tahapan ini aplikasi modul operasional HRMS diimplementasikan berdasarkan pada rancangan yag telah dilakukan pada tahapan sebelumnya. Aplikasi ini dirancang dan diimplementasikan pada PT Mitra Hexa Sejahtera.

\section{Login}

Ketika situs HRMS dibuka, pengguna akan dihadapkan pada informasi awal menú-menu yang tersedia pada modul operasional dan info lainnya, juga disediakan form login bagi pengguna yang sudah terdaftar.

\section{Client}

Pada modul ini super admin dapat melakukan pengelolaan data klien yang bekerja sama dengan PT Mitra Hexa Sejahtera dalam pemenuhan kebutuhan tenaga kerja, seperti menambahkan klien baru dan mengubah informasi klien. Modul ini juga menampilkan informasi lengkap mengenai klien yang bekerja sama dengan PT Mitra Hexa Sejahtera dalam pemenuhan karyawan outsourcing, salah satunya daftar karyawan yang bekerja pada klien tersebut.

\section{Employee}

Pada modul ini super admin dapat melakukan pengelolaan data karyawan outsourcing sesuai dengan bagian yang dipilih. Selain melakukan pengelolaan data karyawan, pengguna juga mendapatkan informasi terkait track record karyawan yang dipilih.

\section{Time and Attendance}

Pada modul ini super admin dapat melakukan pengelolaan data absen dan lembur. Data absen dan lembur saling berhubungan sehingga pengguna dapat mengecek kehadiran dan lembur karyawan dengan mudah. Fitur tambahan lainnya yaitu, absen apel untuk bagian office boy dan cleaning service yang dapat membantu pengguna untuk mengecek kehadiran apel karyawan.

6. Severence Proposal

Pada modul ini super admin dapat melakukan pengelolaan data pemutusan hubungan kerja karyawan, baik itu resign maupun pemutusan kontrak. Selain itu, persetujuan pemutusan hubungan kerja dilakukan langsung oleh pihak-pihak yang berkepentingan untuk melakukan hal ini.

\section{Tracking Contract}

Pada modul ini super admin dapat melakukan tracking kontrak karyawan outsourcing sehingga pengguna dapat mengecek masa kontrak karyawan dan mempersiapkan perekrutan jika terdapat karyawan yang dalam waktu dekat segera habis masa kontraknya. Modul ini juga menampilkan warning jika terdapat karyawan yang segera habis masa kontraknya dengan jangka waktu kurang dari satu bulan yang ditandai dengan status berwarna merah.

\section{Performance Appraisal}

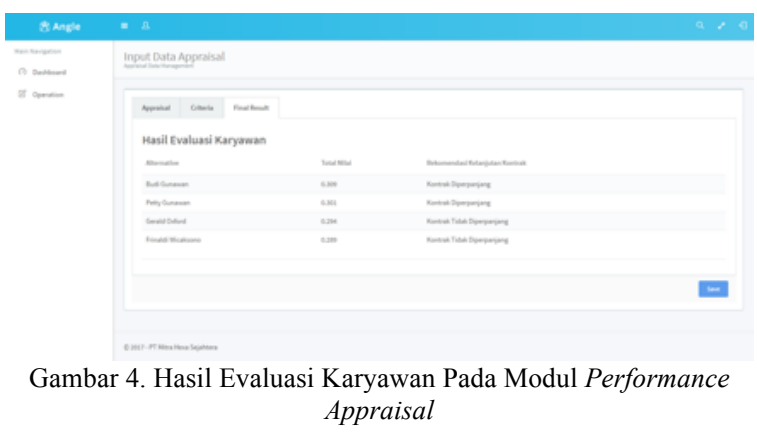

Pada modul ini dimaksudkan untuk melakukan penilaian kinerja karyawan dengan fitur sistem pendukung keputusan menggunakan metode TOPSIS untuk menentukan rekomendasi karyawan yang akan diperpanjang masa kontraknya. Setelah mengisi data absensi karyawan, supervisor dapat melakukan penilaian dengan memilih nama karyawan, nama penilai, dan tanggal penilaian. Kemudian akan muncul tiga kriteria penilaian yaitu, 
kedisiplinan, apel, dan penampilan yang masingmasing menampilkan hasil rekap dari data asbensi karyawan yang telah diisi sebelumnya. Setelah itu, akan muncul hasil rekomendasi kelanjutan kontrak karyawan yang diperpanjang dan tidak diperpanjang kontraknya. Tampilan halaman performance appraisal dapat dilihat pada Gambar 4.

\section{E. Hasil Penentuan Kelanjutan Karyawan Kontrak dengan Metode TOPSIS}

Metode TOPSIS adalah metode alternatif dengan nilai terbesar dan juga dipilih dalam pengambilan keputusan menentukan karyawan yang dapat direkomendasikan untuk diperpanjang kontraknya. Pada penelitian ini menggunakan sampel lima karyawan outsourcing yang akan dipilih untuk direkomendasikan perpanjangan kontraknya di PT Mitra Hexa Sejahtera. Tabel 2 menunjukkan hasil akhir yang diperoleh dengan menggunakan metode TOPSIS.

Evaluasi karyawan kontrak terdiri dari tiga kriteria penilaian, yaitu kedisiplinan, apel, dan penampilan. Parameter penilaian kedisiplinan berdasarkan data kehadiran karyawan, parameter penilaian apel berdasarkan data kehadiran apel, dan parameter penilaian penampilan dari kelengkapan seragam dan kerapihan penampilan. Berdasarkan tiga kriteria inilah karyawan outsourcing akan dievaluasi untuk dipilih dan direkomendasikan perpanjangan kontraknya.

TABEL 2. HASIL EVALUASI KARYAWAN DENGAN METODE TOPSIS

\begin{tabular}{|c|c|l|}
\hline NIK & Nilai $V_{i}$ & Rekomendasi Kelanjutan Kontrak \\
\hline 12.09 .4001 & 0.02 & Kontrak Tidak Diperpanjang \\
\hline 12.09 .4002 & 0.45 & Kontrak Diperpanjang \\
\hline 12.09 .4003 & 0.46 & Kontrak Diperpanjang \\
\hline 12.09 .4004 & 0.30 & Kontrak Diperpanjang \\
\hline 12.09 .4005 & 0.34 & Kontrak Diperpanjang \\
\hline
\end{tabular}

Berdasarkan hasil evaluasi karyawan outsourcing dengan metode TOPSIS, dengan nilai preferensi (Vi) berkisar antara 0,40 sampai 1 menunjukkan bahwa ada dua karyawan yang direkomendasikan dalam pengambilan keputusan kepada karyawan yang akan diperpanjang kontraknya. Sedangkan nilai preferensi yang berada pada kisaran nilai 0,39 - 0 menunjukkan bahwa ada tiga karyawan kontrak adalah kelanjutan dan dua karyawan kontrak tidak diperpanjang.

\section{KESIMPULAN DAN SARAN}

Berdasarkan hasil analisis, perancangan, dan implementasi yang sudah dilakukan sebelumnya, diambil kesimpulan bahwa sistem rekomendasi kelanjutan kontrak untuk karyawan outsourcing telah berhasil dibuat dengan memiliki enam fitur, yaitu fitur client untuk mengelola data klien, fitur employee untuk mengelola data karyawan, fitur time and attendance untuk mengelola data absensi karyawan, fitur severence proposal untuk mengelola data resign dan pemutusan kontrak karyawan. Fitur terakhir yaitu, performance appraisal yang berfungsi sebagai sistem pendukung keputusan untuk evaluasi karyawan outsourcing.

Hasil pengujian yang telah dilakukan adalah sebagai berikut:

1. White-box testing dari hasil graph matrix maka dapat diketahui nilai cyclomatic complexity-nya adalah tiga sehingga dapat disimpulkan bahwa TOPSIS memiliki prosedur yang sederhana dan memiliki tingkat resiko yang rendah.

2. Black-box testing dapat disimpulkan bahwa hampir seluruh fungsi modul operasional telah berjalan sesuai skenario pengujian, namun terdapat satu fungsi yang masih terdapat bug pada tracking contract, yaitu ketika tanggal start date lebih dari tanggal hari ini maka progress bar tidak dapat menampilkan warna status kontrak.

3. User Acceptance Test (UAT) yang telah dilakukan, dapat disimpulkan bahwa hasil pengujian menunjukkan $89 \%$ modul telah berjalan dengan baik dan hampir seluruh fungsi dan fitur yang tersedia pada sistem telah berjalan sesuai rancangan yang dibuat sebelumnya.

\section{REFERENSI}

[1] Alamelu, R., et al. "Techno-Management Perspective of HRIS-An Urban Study." Indian Journal of Science and Technology 9.27 (2016).

[2] Anwar, Ashraf. "A Review of RUP (Rational Unified Process)." International Journal of Software Engineering (IJSE) 5.2 (2014): 12-19.

[3] Mohd, Haslina, et al. "Adapting Rational Unified Process (RUP) approach in designing a secure e-Tendering model." AIP Conference Proceedings. Eds. Faizatul Akmar Abdul Nifa, Mohd Nasrun Mohd Nawi, and Azham Hussain. Vol. 1761. No. 1. AIP Publishing, 2016.

[4] Thawari, Amit S., Dr. S. E. Yedey "Study of Codeigniter Technology" International Journal Of Research In Computer \& Information Technology (Ijrcit) , Vol. 1, Special Issue 2, July-2016

[5] MariaDB, 2012. Why MariaDB. [Online] Available at:https://mariadb.com/products/why-mariadb [Diakses 21 Maret 2017].

[6] Wijaya, Kelvin, Hans Wowor, and Virginia Tulenan. Sistem Pendukung Keputusan Penerima Beasiswa dengan Metode Technique For Order Preference By Similarity To Ideal Solution Di Universitas Sam Ratulangi Manado. Jurnal Teknik Informatika Universitas Sam Ratulangi 5.1 (2015).

[7] Ritonga, Siti Kholijah. "Sistem Informasi Penilaian Kinerja Karyawan Menggunakan Metode Technique For Other Reference By Similarity To Ideal Solution." Jurnal Pelita Informatika Budi Darma 4.2 (2013). 
[8] Özder, E. H., T. Eren, and S. Ö. Çetin. "Supplier selection with TOPSIS and goal programming methods: A case study." 19h International Research/Expert Conference "Trends in the Development of Machinery and Associated Technology", Journal of Trends in the Development of Machinery and Associated Technology. 2015.

[9] Perdana, Nuri Guntur, and Tri Widodo. "Sistem Pendukung Keputusan Pemberian Beasiswa Kepada Peserta Didik Baru Menggunakan Metode TOPSIS." Semantik 2013 3.1 (2013): 265-272.
[10] Mallu, Satriawaty. "Sistem Pendukung Keputusan Penentuan Karyawan Kontrak Menjadi Karyawan Tetap Menggunakan Metode TOPSIS." Jurnal Ilmiah Teknologi Informasi Terapan 1.2 (2015).

[11] Pressman, R. S. \& Maxim, B. R., 2015. Software Engineering: A Practitioner's Approach. $8^{\text {th }}$ ed. New York: McGraw-Hill Education. 